\title{
The Winter Ozone Minimum over the Subtropical Northwestern Pacific
}

\author{
Jianyu HAN, Koji YAMAZAKI \\ Graduate School of Environmental Earth Science, Hokkaido University, Sapporo, Japan \\ and \\ Masanori NIWANO \\ Department of Geophysics, Kyoto University, Kyoto, Japan
}

(Manuscript received 16 February 2004, in final form 25 October 2004)

\begin{abstract}
Over the subtropical northwestern Pacific, a prominent ozone minimum of less than 235 Dobson Units (DU) is observed in winter, with extremely low values of less than 200 DU occurring occasionally over this region for short time periods (days to weeks). In this study the vertical structure of this ozone minimum is examined using a 9 year (1991-2000) average of the total ozone mapping spectrometer (TOMS) and Halogen Occultation Experiment (HALOE) data. It is found that the ozone minimum is mainly stratospheric origin with two distinct low-ozone layers in the stratosphere, one in the middle stratosphere of 10-15 hPa, and the other in the lower stratosphere of 40-60 hPa. The mid-stratospheric low-ozone layer is attributed to southward transport of high-latitude low-ozone air by atmospheric circulation in wintertime associated with the Aleutian High, which is simulated successfully using a simple chemical transport model. The extremely low ozone was observed in December 2001 over the subtropical northwestern Pacific. This case is also examined by ozonesonde observations at Naha $\left(26^{\circ} 12^{\prime} \mathrm{N}\right.$, $\left.127^{\circ} 41^{\prime} \mathrm{E}\right)$ and the model. Both the results from the 9 year climatological field, and the December 2001 field, show that the wintertime total ozone minimum over the subtropical northwestern Pacific is substantially dynamical in origin.
\end{abstract}

\section{Introduction}

The total amount of ozone is generally low in the tropics in winter. In particular, a total ozone minimum of less than 235 DU occurs over the subtropical northwestern Pacific in January climatology, based on Total Ozone Mapping Spectrometer (TOMS) data (Fig. 1). The TOMS data spans from November 1978 through May 1993 on board Nimbus 7, and from July 1996 through March 2003 on board Earth Probe. The TOMS data provides the

Corresponding author: Jianyu Han, Graduate School of Environmental Earth Science, Hokkaido University, N10, W5, Sapporo 060-0810, Japan. E-mail: hjy@ees.hokudai.ac.jp

(C) 2005, Meteorological Society of Japan daily global ozone distribution with a resolution of $1^{\circ}$ in latitude and $1.25^{\circ}$ in longitude. Although many studies on the tropical ozone and its variation have been made (Randel and Cobb 1994; Shiotani 1992; Shiotani and Hasebe 1994), there are few studies on the winter ozone minimum over the subtropical western Pacific region. On a daily basis, extremely low values of less than 200 DU sometimes appear over this region. Figure 2 shows the ozone minimum in the region $9.5-29.5^{\circ} \mathrm{N}, 100.5-180.5^{\circ} \mathrm{E}$ from winter daily TOMS data from 1978 to 2003. The lowest value of 188 DU was observed on 7 and 15 December 2001, and this low-ozone region has been pointed out by Kawahira et al. (2002). Zhou et al. (2003) analyzed the year-toyear ozone variation over this region for the 


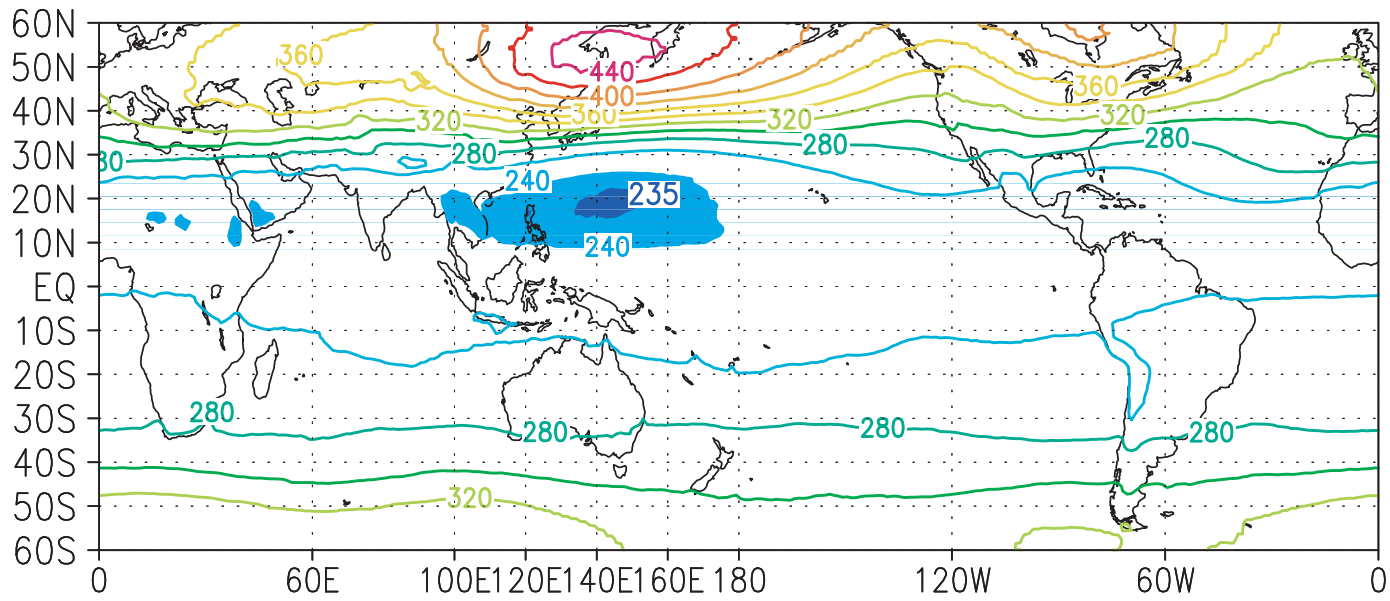

Fig. 1. January (1979-2002) total ozone climatology from the TOMS data (DU). Values less than 240 DU are shaded.

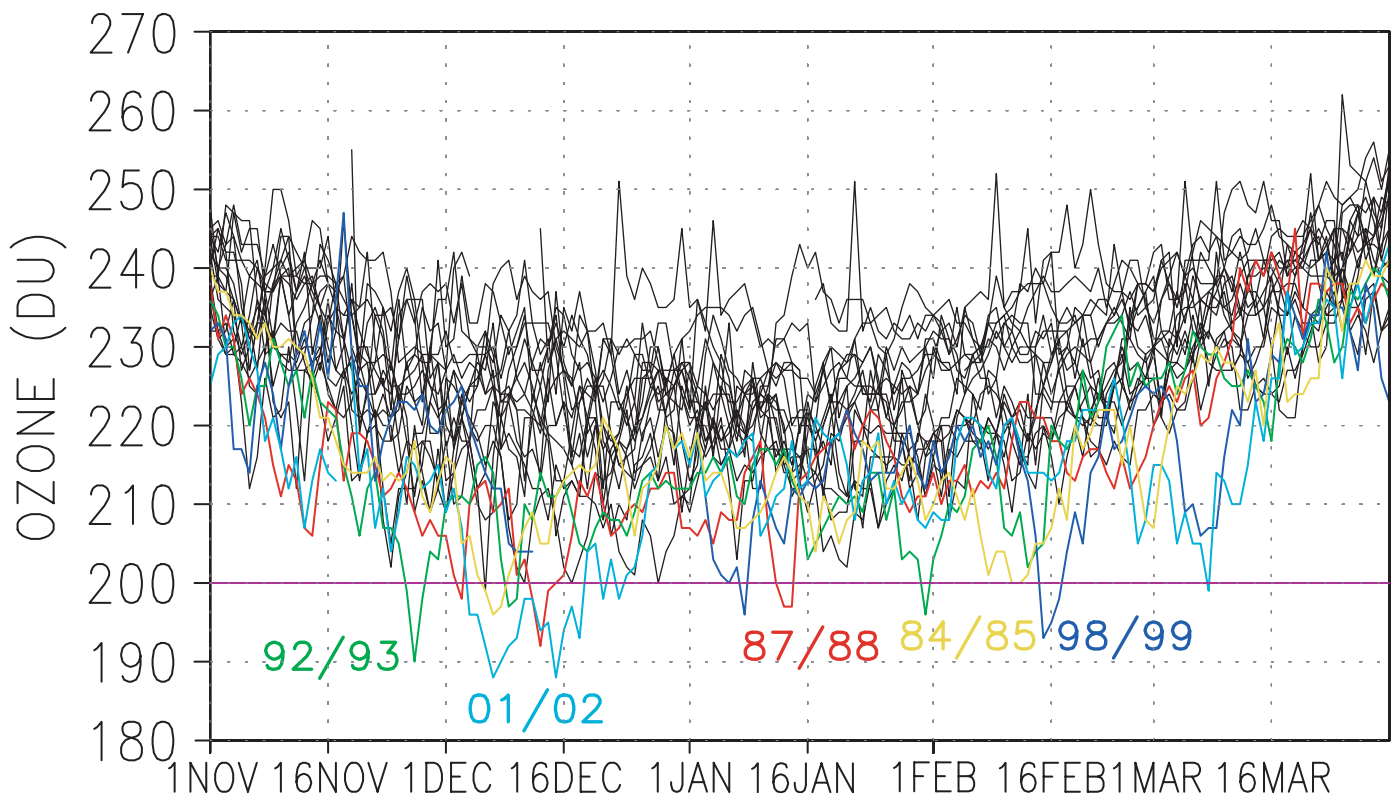

Fig. 2. The daily minimum value of total ozone in the region $9.5-29.5^{\circ} \mathrm{N}, 100.5-180.5^{\circ} \mathrm{E}$ during winter (November to March) for the period from 1978 to 2003. The total ozone data is based on the TOMS data. Vertical axis is DU. Winters in 1984/85, 1987/88, 1992/93, 1998/99, and 2001/02, when the minimum ozone exhibited less than 200 DU, are denoted by color lines.

period from 1996 to 2002 using a statistical regression method and a nudging chemical transport model (CTM). In their nudging CTM, the zonal wind, the meridional wind, and the temperature of the model are forced toward the European Centre for Medium Range Weather Forecasts (ECMWF) data with a relaxation time of 1 day. Their results showed that the equa- torial quasi-biennial oscillation (QBO) mostly controls the interannual variability of total ozone over the region. The westerly shear in the equatorial lower stratosphere is associated with downward motion anomalies in the equatorial belt, and compensating upward motion anomalies in the subtropical belt (Plumb and Bell 1982; Seol and Yamazaki 1998; Niwano 
and Shiotani 2001; Niwano et al. 2003). Since the lifetime of ozone in the lower stratosphere is quite long, this upward motion anomalies bring the lower ozone concentrations of lower altitudes to the higher altitudes below the ozone number density maximum height (about $20 \mathrm{hPa}$ ), and cause low ozone anomalies over the subtropical region in a westerly phase of the QBO. In fact, the phase of the QBO in December 2001 was in a westerly phase when the extremely low ozone was observed over the subtropical northwestern Pacific. Over the region, Zhou et al. (2003) showed that heterogeneous reaction processes have smaller effects on the ozone variation, and hence the low ozone should be caused dynamically.

To date, few studies have been made on this wintertime subtropical ozone minimum, and the reason for the minimum existence has yet to be clarified. In this study, the vertical structure of the ozone minimum, and the dynamical cause of the minimum are examined using the data of the Halogen Occultation Experiment (HALOE) aboard the Upper Atmosphere Research Satellite (UARS), and TOMS data. A simple two-dimensional chemical transport model is used to describe the ozone depletion in the middle stratosphere. We analyze the wintertime ozone anomaly for 9 years of the HALOE climatology in Sections 3-5, and focus on an extreme case in 2001 in section 6 . The data used in this study is described in section 2 . In section 3 the vertical profile of the ozone over the ozone minimum region is shown. In section 4, a simple chemical transport model is introduced, and the model results are described in section 5 . The extremely low ozone case in December 2001 is examined in section 6, and finally a summary is given in section 7 .

\section{Data}

The primary ozone data used in this study is HALOE/UARS version 19 data for the period from October 1991 through May 2000 (Russell et al. 1993). The HALOE data used has 85 levels from $316 \mathrm{hPa}$ to $0.50 \mathrm{hPa}$ (at about $0.5 \mathrm{~km}$ intervals), with a horizontal resolution of $24^{\circ}$ in longitude and $2.5^{\circ}$ in latitude (Niwano and Shiotani 2001). The averaged data of sunrise and sunset measurements are employed in this study. As the HALOE data is sparse in temporal and horizontal resolutions, only monthly climatology is used in this study. The TOMS data is used for total ozone and its explanation was given in the Introduction.

The ECMWF twice-daily wind data is used for the simple chemical transport model, from October 1991 through March 2000.

We use ozonesonde observation data at NAHA $\left(26^{\circ} 12^{\prime} \mathrm{N}, 127^{\circ} 41^{\prime} \mathrm{E}\right)$ from 1989 to 2001 , provided by Japan Meteorological Agency (JMA) to validate the simulation for an extreme low ozone case in December 2001.

\section{Vertical profile of ozone over the subtropical northwestern Pacific}

In order to clarify the stratospheric and tropospheric contributions to the total ozone minimum, the stratospheric ozone (above $100 \mathrm{hPa}$ ) was analyzed by vertically integrating HALOE ozone data, and the tropospheric ozone (below $100 \mathrm{hPa}$ ) was analyzed by subtracting the stratospheric ozone from the TOMS total ozone for the December, January and February (DJF) mean (Fig. 3). This technique is the same as that employed by Fishman et al. (1990), and Fig. 3 of the present study is similar to Figs. 7a, $8 \mathrm{a}$, and $9 \mathrm{a}$ of their study, though they did not discuss the subtropical ozone minimum. The tropospheric ozone is low over the tropical $\mathrm{Pa}-$ cific, but the ozone minimum over the northwestern Pacific is not seen. On the other hand, the stratospheric ozone exhibits a clear minimum over the subtropical northwestern Pacific. At $20^{\circ} \mathrm{N}, 144^{\circ} \mathrm{E}$, the total ozone in DJF is 13.6 DU less than the zonal mean. The tropospheric ozone contributes $2.7 \mathrm{DU}(20 \%)$, and the stratospheric ozone contributes 10.9 DU (80\%) to this reduction. Thus, the depletion occurs mainly in the stratosphere.

The vertical profile based on the 9-year (1991-2000) average of the HALOE data is examined to determine where the low-ozone layer is located in the stratosphere. Figure 4 shows the vertical profile of deviation from zonal mean ozone at $20^{\circ} \mathrm{N}, 144^{\circ} \mathrm{E}$, where the ozone minimum occurs. Both mixing ratio in ppmv and ozone amount per layer in DU are shown in the figure. Each layer is about $500 \mathrm{~m}$ thick. It is clear that two distinct ozone mixing ratio minima exist, one at $10-15 \mathrm{hPa}$, and the other at $40-60 \mathrm{hPa}$. These two vertical layers are responsible for the depletion leading to the northwestern subtropical ozone minimum. 

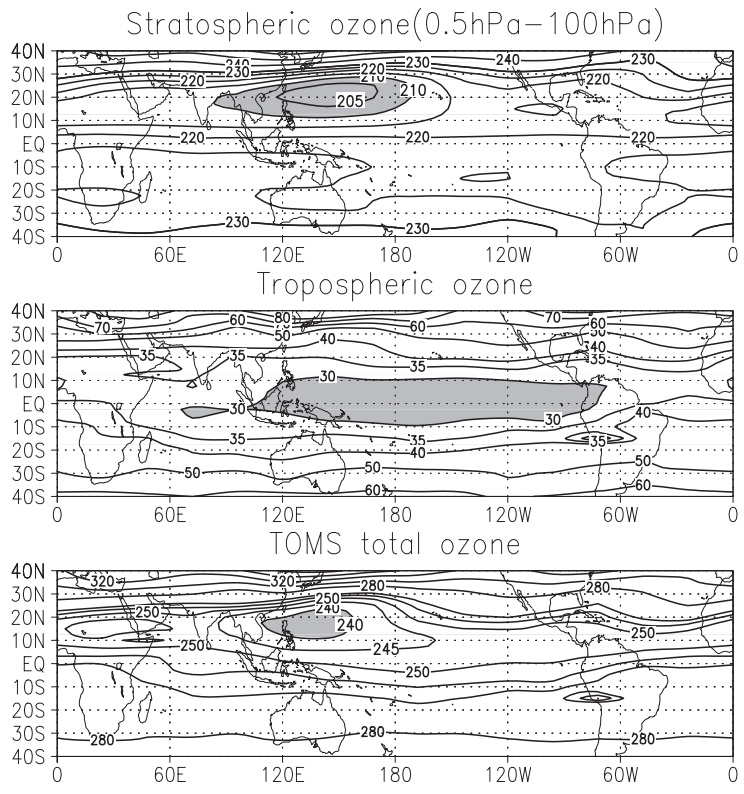

Fig. 3. (Top) Stratospheric ozone amount above $100 \mathrm{hPa}$ in winter (December, January and February). (Middle) Tropospheric ozone amount below $100 \mathrm{hPa}$ in winter (DJF). (Bottom) TOMS total ozone in winter (DJF). The stratospheric ozone is based on the 9-year average (1991-2000) of the HALOE data and the tropospheric ozone is analyzed by subtracting the stratospheric ozone from the TOMS total ozone data. Contour interval is 5 DU. Values less than 210 DU (top), 30 DU (middle), and 240 DU (bottom) are shaded.

Although the middle stratospheric minimum $(10-15 \mathrm{hPa})$ is stronger than the lower stratospheric minimum $(40-60 \mathrm{hPa})$ in terms of mixing ratio, the lower stratospheric layer contributes more to the depletion of total ozone because of a density effect. As mentioned before, the stratospheric ozone at $20^{\circ} \mathrm{N}, 144^{\circ} \mathrm{E}$, in DJF is 10.9 DU less than the zonal mean. The middle stratospheric ozone $(5-25 \mathrm{hPa})$ contributes $3.6 \mathrm{DU}$ ( $26 \%$ of the total ozone and $33 \%$ of the stratospheric ozone), and the lower stratospheric ozone $(25-100 \mathrm{hPa})$ contributes $7.4 \mathrm{DU}$ (54\% of the total ozone and $68 \%$ of the stratospheric ozone) to this reduction. Above $5 \mathrm{hPa}$, the ozone contributes $0.1 \mathrm{DU}$ ( $1 \%$ of the stratospheric ozone) increase to the total ozone.

Figure 5 shows the ozone amount (DU) in the middle stratosphere $(5-25 \mathrm{hPa})$, in the lower

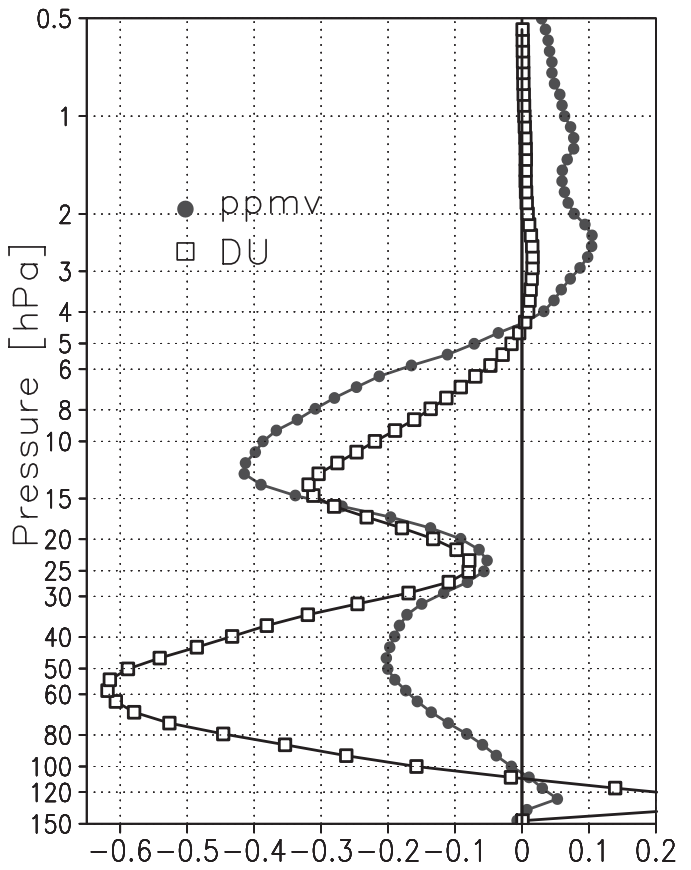

Fig. 4. Vertical profile of eddy ozone (deviation from the zonal mean) at $20^{\circ} \mathrm{N}$, $144^{\circ} \mathrm{E}$ in winter (DJF) based on the 9-year average (1991-2000) of HALOE data. Both mixing ratio and ozone amount per layer are shown. Each layer is about $500 \mathrm{~m}$ thick. Vertical axis: $\mathrm{hPa}$. Horizontal axis: ppmv and DU per layer.

stratosphere $(25-100 \mathrm{hPa})$ and the sum of both $(5-100 \mathrm{hPa})$, averaged for DJF and the corresponding zonal averages are shown in Fig. 6. The ozone amount in the middle stratosphere decreases from the equator toward high latitudes, whereas that in the lower stratosphere decreases from the high latitudes toward the equator. In the lower stratospheric layer, the ozone gradually decreases from $20^{\circ} \mathrm{S}$ to $10^{\circ} \mathrm{N}$ and rapidly increases from $10^{\circ} \mathrm{N}$ to the north (bottom line in Fig. 6). On the other hand, the ozone in the middle stratospheric layer gradually decreases from the peak of $5^{\circ} \mathrm{S}$ toward north (middle line in Fig. 6). As a result, the stratospheric total ozone has a broad minimum around $15^{\circ} \mathrm{N}$ (top line in Fig. 6). As for the horizontal maps shown in Fig. 5, although the ozone contours meander in the subtropical northwestern Pacific, indicating ozone troughs, no closed ozone contours are found in either 

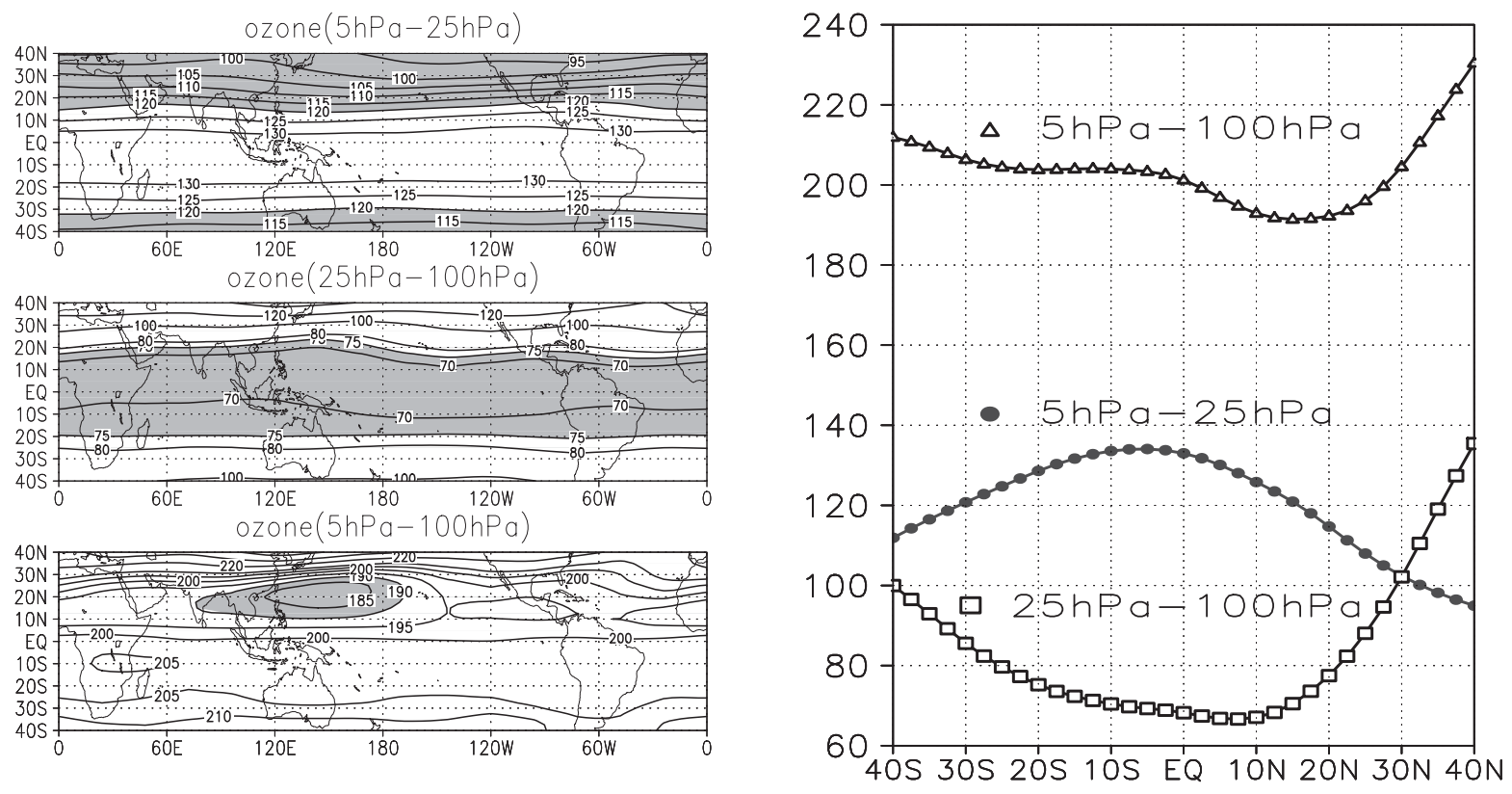

Fig. 5. (Top) The middle stratospheric ozone $(5-25 \mathrm{hPa})$ in winter (DJF). (Middle) The lower stratospheric ozone $(25-100 \mathrm{hPa})$ in winter (DJF). (Bottom) The sum (5-100 hPa) in winter (DJF). The figure is based on the 9-year average (1991-2000) of HALOE data. Contour interval is 5 DU. Values less than 120 DU (top), 75 DU (middle), and 190 DU (bottom) are shaded.

layer. It is clear that the stratospheric ozone minimum appears as the sum of the middle and lower stratospheric ozone troughs.

The seasonal variation of the eddy ozone (deviation from zonal mean) at the ozone minimum over the region is shown in Fig. 7. A clear anomaly in the stratospheric ozone is seen from December to March. The minimum in the middle stratosphere occurs in December, whereas that in the lower stratosphere occurs in February. The lower stratospheric contribution is larger than the middle stratospheric contribution to the whole stratospheric ozone from January to March. In December, both contributions are comparable. As a result, the minimum of the sum $(5-100 \mathrm{hPa})$ occurs in December.

The minimum in the lower stratosphere is probably caused by northward advection of low-ozone air from the equatorial region in wintertime, which is brought from the troposphere into the stratosphere by strong upward

Fig. 6. Same as in Fig. 5 except for the zonal mean ozone. The middle stratospheric ozone $(5-25 \mathrm{hPa})$ is shown by closed circles. The lower stratospheric ozone $(25-100 \mathrm{hPa})$ is shown by open squares. The sum $(5-100 \mathrm{hPa})$ is denoted by open triangles.

motion over the maritime continent. The similar mechanism, which explains low water vapor in the subtropical northwestern Pacific, has been discussed (Randel et al. 2001; Hatsushika and Yamazaki 2003). In the lower stratosphere, the ozone mixing ratio increases with latitude. Thus, northward advection from the equator toward the subtropics reduces the ozone in the subtropics. In the middle stratosphere, on the other hand, the ozone maximum is located at about $10^{\circ} \mathrm{S}$, and the ozone density decreases toward northern high-latitudes. The northern subtropical Pacific is located to the south of the Aleutian High, and it is a reasonable hypothesis that this anticyclonic circulation brings lowozone air in the high latitude to the subtropical Pacific.

\section{A simple chemical transport model}

In order to confirm the above hypothesis regarding the middle stratospheric ozone minimum, a simple chemical transport model for ozone mixing ratio at the $10 \mathrm{hPa}$ is constructed. 


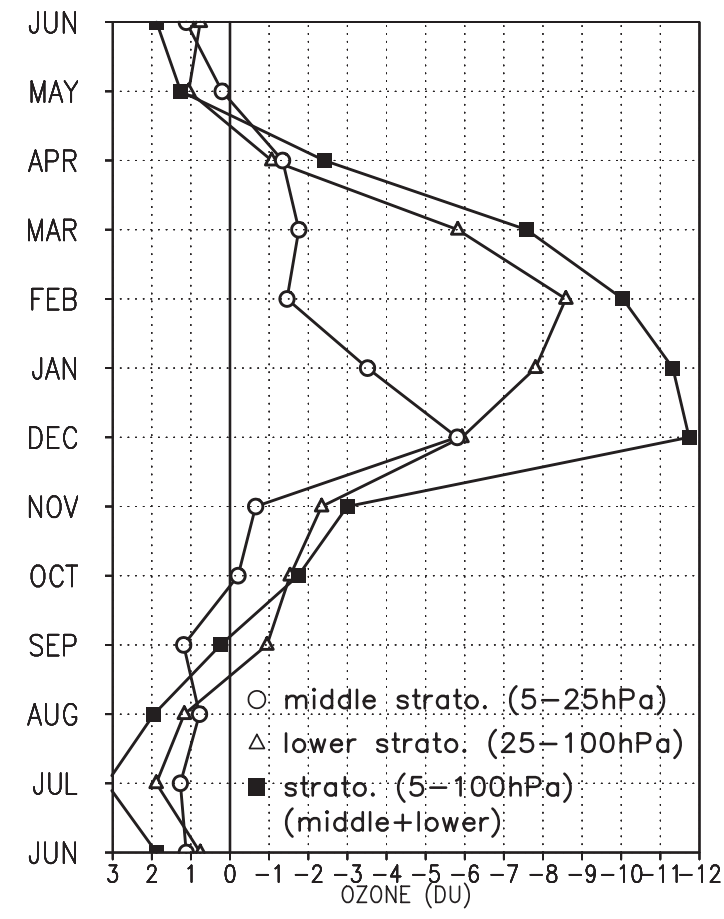

Fig. 7. Temporal variation of eddy ozone amount (deviation from the zonal mean) at $20^{\circ} \mathrm{N}, 144^{\circ} \mathrm{E}$ based on HALOE data. Open circles denote the middle stratospheric ozone $(5-25 \mathrm{hPa})$, open triangles denote the lower stratospheric ozone (25-100 hPa), and closed squares denote the sum of the two, the stratospheric ozone $(5-100 \mathrm{hPa})$. Unit in the horizontal axis is DU and the vertical axis denotes month.

The continuity equation for ozone mining ratio $\chi$ in a pressure coordinate is expressed as follows.

$$
\frac{d \chi}{d t} \equiv \frac{\partial \chi}{\partial t}+u \frac{\partial \chi}{\partial x}+v \frac{\partial \chi}{\partial y}+\omega \frac{\partial \chi}{\partial p}=S,
$$

where $u$ and $v$ are zonal and meridional winds, and $\omega$ is vertical $p$-velocity. $S$ is a source-sink term. As the ozone density peaks near $10 \mathrm{hPa}$ in the vertical profile, the effect of vertical advection is considered to be small. The mean vertical velocity near $10 \mathrm{hPa}$ in the tropics is estimated to be $0.8 \mathrm{~mm} / \mathrm{s}$ in January from the HALOE data (Niwano et al. 2003), which corresponds to $0.1 \mathrm{hPa} /$ day of $\omega$. The vertical gradient of ozone mixing ratio is about $0.3 \mathrm{ppmv} /$
$\mathrm{hPa}$ at $10 \mathrm{hPa}$. As a result, the vertical advection term is about $0.03 \mathrm{ppmv} /$ day. On the other hand, the meridional advection term is estimated as $0.5 \mathrm{ppmv} /$ day, using a typical meridional wind speed of $5 \mathrm{~m} / \mathrm{s}$, and difference of $1.2 \mathrm{ppmv}$ in ozone mixing ratio between $20^{\circ} \mathrm{N}$ and $30^{\circ} \mathrm{N}$ in January. The vertical advection term is at least one order of magnitude smaller than the horizontal advection term near $10 \mathrm{hPa}$. Thus, the ozone mixing ratio $\chi$ is assumed to be transported by a two-dimensional horizontal wind field as an approximation in this study. The photo-chemical term is expressed by a Newtonian form, so as to force the value to the photo-chemical equilibrium value $\chi^{*}$, with a time constant $\tau$. The equation for the ozone mixing ratio is modified as follows.

$$
\frac{\partial \chi}{\partial t}=-u \frac{\partial \chi}{\partial x}-v \frac{\partial \chi}{\partial y}+k \nabla^{2} \chi-\left(\chi-\chi^{*}\right) / \tau,
$$

where $k$ is a diffusion coefficient, and the Laplacian operator $\nabla^{2}$ is 2-dimensional horizontal operator. The diffusion term is included to prevent a computational instability and the diffusion coefficient $k$ was set at $1.8 \times 10^{5} \mathrm{~m}^{2} \mathrm{~s}^{-1}$, corresponding to the diffusion time-scale of 5 days. Decreasing $k$ to $3.0 \times 10^{4} \mathrm{~m}^{2} \mathrm{~s}^{-1}$ (diffusion time-scale of 30 days) resulted in essentially the same results. The results presented in this study are insensitive to $k$. The model domain is set from the $10^{\circ} \mathrm{S}$ to $75^{\circ} \mathrm{N}$, and ozone values at the boundaries are specified as climatological values. The wind is given by the ECMWF daily data, and an upwind scheme, which uses a backward difference in space concerning wind direction, and ensures a computational stability (e.g., Fujii 1994), is used for the advection terms. Even though the upwind scheme was used, instability occurred after one month without the diffusion term. Starting from a zonally uniform initial condition, the model was integrated from October to March every year to match the period of HALOE data. The time constant $\tau$ varied from 10 to 17 days from south to north (Dessler 2000). The values of $\chi^{*}$ were given based on the zonal-mean, 9-year mean HALOE data from $10^{\circ} \mathrm{S}$ to $40^{\circ} \mathrm{N}$, and based on Keating and Young (1985) and Dutsch (1979) from $42.5^{\circ} \mathrm{N}$ to $75^{\circ} \mathrm{N}$. A sensitivity test was also conducted for the model parameter $\tau$. Increasing $\tau$ to 30 days resulted in an increase in the magnitude of the ozone minima over the sub- 

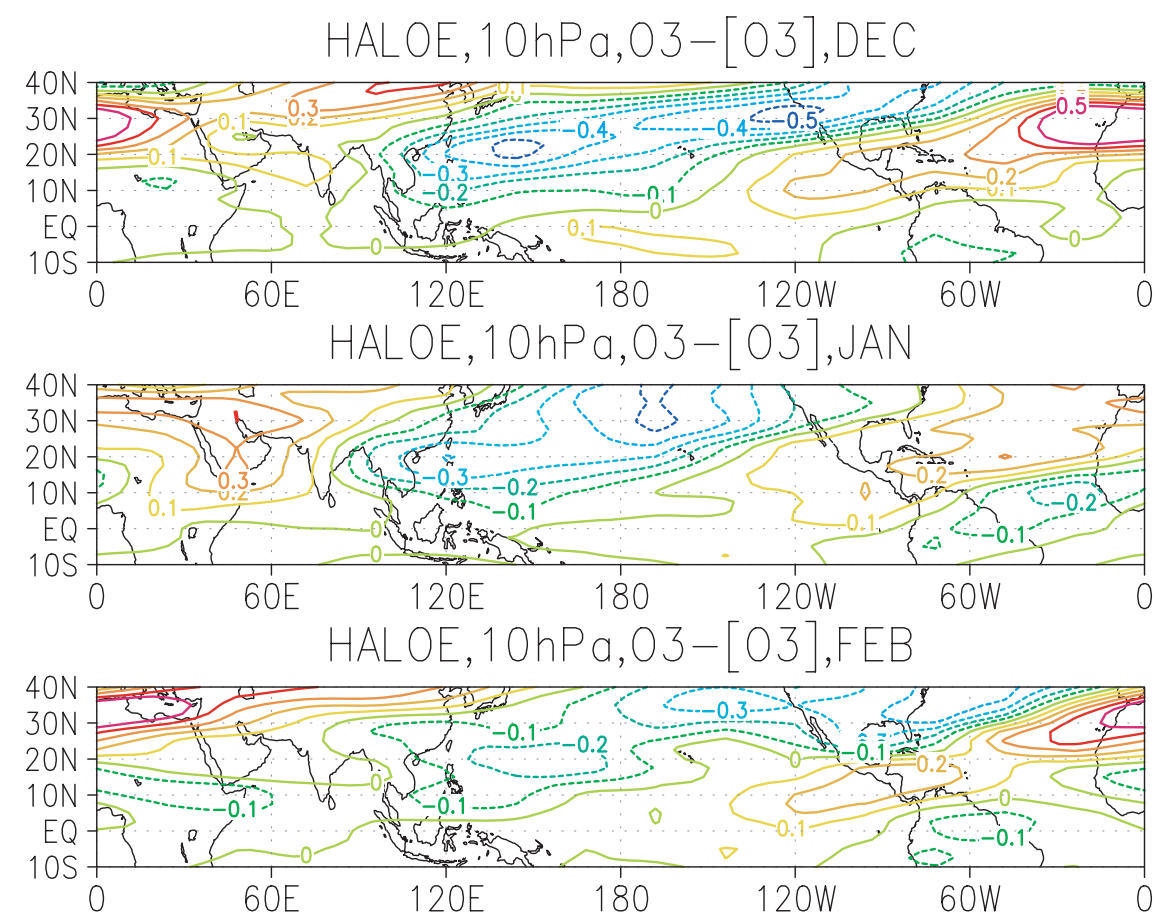

Fig. 8. Observed eddy ozone (deviation from the zonal mean) at $10 \mathrm{hPa}$ from the 9-year average (1991-2000) of HALOE data for December (top), January (middle) and February (bottom). Contour interval is 0.1 ppmv.

tropical northwestern Pacific, as expected, but the differences were quite small. Thus, it was confirmed that the results are insensitive to the choice of parameters.

\section{Results of the model simulation}

Figure 8 shows the observed eddy ozone field (deviation from the zonal mean) from the 9year average of the HALOE data at $10 \mathrm{hPa}$, and Fig. 9 shows the corresponding simulated field at $10 \mathrm{hPa}$. Observed spatial patterns such as low ozone over the subtropical Pacific and high ozone from the subtropical Atlantic to Central America are captured well by this simple model. The simulated eddy ozone over the subtropical northwestern Pacific exhibits a peak in the ozone minimum in December, which accords with the observation. This December peak is attributed to seasonal variations in the meridional gradient of ozone, and the strength of the Aleutian High. In December the zonal mean ozone mixing ratio of middle latitudes (from $40^{\circ} \mathrm{N}$ to $70^{\circ} \mathrm{N}$ ) is the lowest, and thus the meridional gradient of ozone is the largest in midlatitudes. In addition, the northerly wind south of the Aleutian High is the strongest in December than other months. These two factors contribute to bring high-latitude low-ozone air into the subtropical north Pacific. Although the model is simple, the essential features of the observed eddy ozone fields are simulated very well, confirming that the middle stratosphere ozone minimum over the subtropical Pacific is attributable to southward transport of low-ozone air associated with the Aleutian High. We also applied this model on $850 \mathrm{~K}$ isentropic surface, which is close to $10 \mathrm{hPa}$. The results are almost the same as those calculated at $10 \mathrm{hPa}$.

\section{Extreme ozone minimum in December 2001}

The lowest value of 188 DU was observed on 7 and 15 December 2001 by TOMS (Fig. 2). Ozonesonde observations were made on $5,20,26$ December 2001 at Naha $\left(26^{\circ} 12^{\prime} \mathrm{N}, 127^{\circ} 41^{\prime} \mathrm{E}\right)$, but sonde observation did not reach $10 \mathrm{hPa}$ on 20 and 26 December. We chose 5 December to examine the lowest value in December 2001, and to validate our model. Figure 10 shows the 

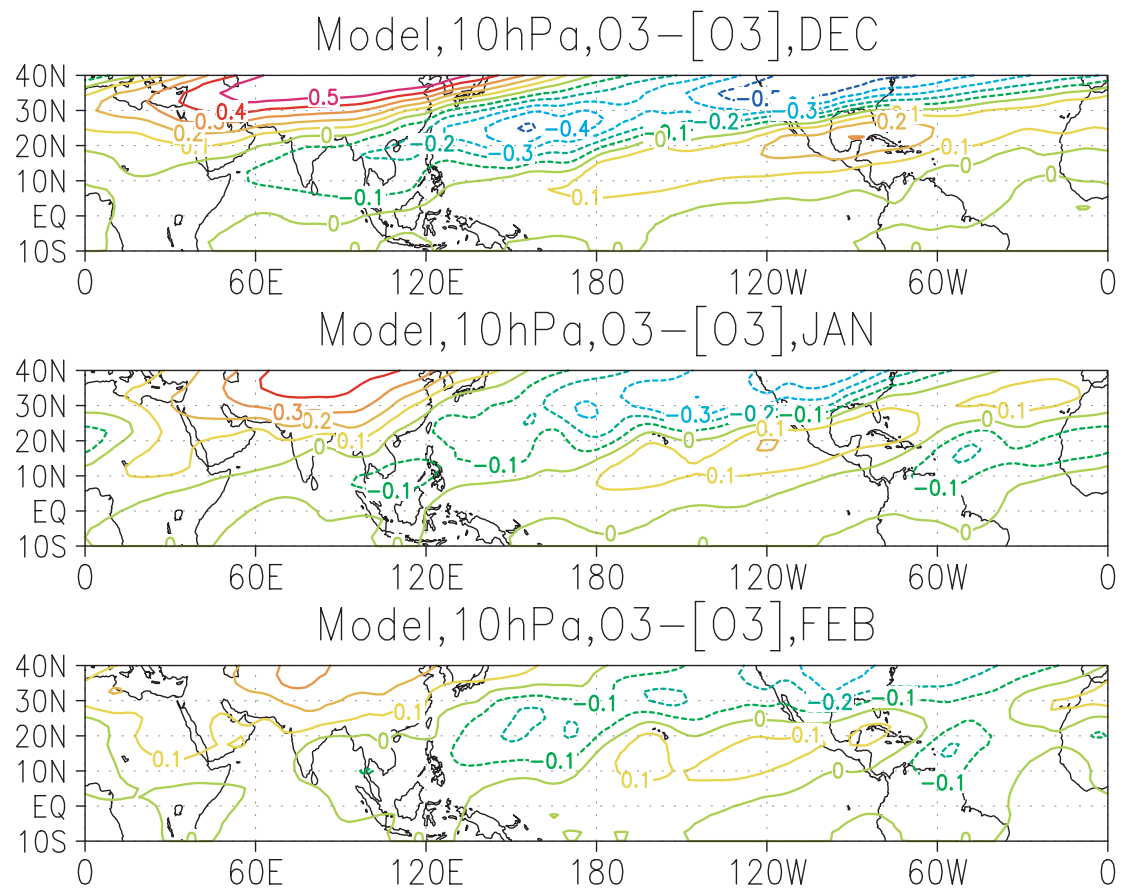

Fig. 9. Same as in Fig. 8 except for simulated results by a simple chemical transport model.

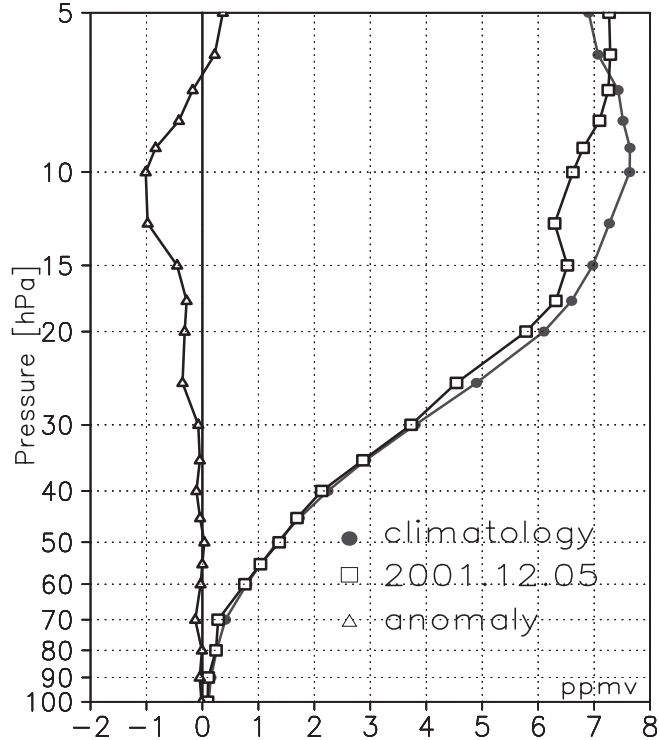

Fig. 10. Vertical profile of anomaly from December climatology ozone (from 1989 to 2001 ) at $26^{\circ} 12^{\prime} \mathrm{N}, 127^{\circ} 41^{\prime} \mathrm{E}$ on $5 \mathrm{De}$ cember 2001 based on ozonesonde data (vertical axis: hPa). vertical profiles of ozone mixing ratio at Naha on 5 December 2001. It has an anomaly of about 1 ppmv from the climatology at $10 \mathrm{hPa}$ in the middle stratosphere. The lower stratospheric ozone shows slight negative anomalies, and the tropospheric ozone shows no anomalies. The contribution of the middle stratosphere $(7-30 \mathrm{hPa})$ for negative anomaly of the total ozone from climatology is $8.3 \mathrm{DU}$, and that of the lower stratosphere $(30-100 \mathrm{hPa})$ is 2.5 DU. It is clear that the low value of total ozone on 5 December 2001 is due to the middle stratospheric minimum.

Figure 11 shows the simulated ozone mixing ratio at $10 \mathrm{hPa}$ on 5 December 2001 together with horizontal wind vectors. The red circle denotes the location of Naha. As the Aleutian High is strong in this period, the circulation of the Aleutian High brings low-ozone air in the high latitude, to Naha through the North $\mathrm{Pa}$ cific. The simulated ozone mixing ratio at Naha is about 6.5 ppmv, which accords with the ozonesonde observation (Fig. 10). Figure 12 shows the anomaly of simulated ozone mixing ratio at $10 \mathrm{hPa}$, from the December climatology during the period from 1989 to 2001, which is the same 


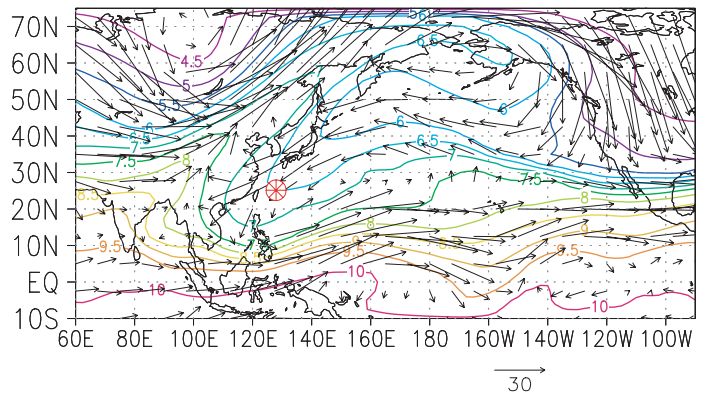

Fig. 11. Simulated ozone mixing ratio at $10 \mathrm{hPa}$ on 5 December 2001 by a simple chemical transport model. Contour interval is 0.5 ppmv. Vectors denote the horizontal winds from the ECMWF data. The location of NAHA $\left(26^{\circ} 12^{\prime} \mathrm{N}\right.$, $127^{\circ} 41^{\prime} \mathrm{E}$ ) is marked in the map.

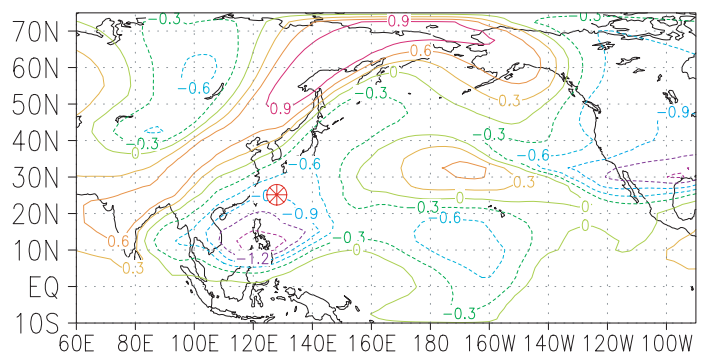

Fig. 12. Anomaly of simulated ozone mixing ratio at $10 \mathrm{hPa}$ on 5 December 2001 from the mean December values for the period from 1989 to 2001. Contour interval is $0.3 \mathrm{ppmv}$. The location of NAHA is marked in the map.

period as observation shown in Fig. 10. From Fig. 12, we see that the simulated anomaly at Naha is -0.9 ppmv, which accords with the observed anomaly of -1 ppmv (Fig. 10). Therefore, the present model successfully simulates the extreme low ozone in December 2001.

To confirm the air around NAHA came from the Aleutian High region, we calculated isobaric backward trajectories at $10 \mathrm{hPa}$ using the ECMWF twice-daily data. Figure 13 shows 8-day backward trajectories starting from the region $126-129^{\circ} \mathrm{E}, 25-28^{\circ} \mathrm{N}$ on $12 \mathrm{UTC}, 5 \mathrm{De}-$ cember 2001. The initial positions of air parcels are placed in 1 degree intervals both in latitude and longitude, and total number of trajectories is $16(=4 \times 4)$. The color of trajectory changes with one day interval. It is shown that the air around NAHA came from the Aleutian region, and the traveling time is $2-4$ days. The 3-dimensional trajectories give similar results. From India to northeast Siberia through northern China, high ozone is extended from low latitudes (Figs. 11 and 12). This tongueshaped high ozone belt must be caused by dynamical transport of high ozone, from low latitudes to the west of the Aleutian High. To demonstrate this, backward trajectories from the Siberia region $126-129^{\circ} \mathrm{E}, 55-58^{\circ} \mathrm{N}, 30$ degrees north of the NAHA region are also shown in Fig. 13. The figure shows that it takes only 2 days from $30^{\circ} \mathrm{N}$ to the Siberian region, and this rapid flow brings low-latitude high ozone. The Aleutian High plays an important role for transport of ozone between high-latitudes and low-latitudes in the middle stratosphere.

\section{Summary and discussion}

The causes of the prominent ozone minimum observed in winter over the subtropical northwestern Pacific were investigated using TOMS and HALOE data, by examining the vertical structure of ozone. The stratospheric ozone was found to be the main contributor to the depletion leading to the ozone minimum. Two distinct low-ozone layers were identified in the stratosphere, a middle stratosphere layer (10$15 \mathrm{hPa}$ ) and a lower stratosphere layer (40$60 \mathrm{hPa}$ ). The contributing percentages of winter total ozone deviation from the zonal mean at $20^{\circ} \mathrm{N}$ are $54 \%$ from the lower stratosphere, $26 \%$ from the middle stratosphere, and residual $20 \%$ from the troposphere. The cause of the mid-stratospheric low-ozone layer was attributed to southward transport of high-latitude low-ozone air by atmospheric circulation associated with the Aleutian High, as confirmed by a simple chemical transport model calculation for the ozone minima at $10 \mathrm{hPa}$.

The lowest total ozone value of $188 \mathrm{DU}$ was observed on 7 and 15 December 2001, when the equatorial QBO was in a westerly phase. This extreme low ozone case was examined using ozonesonde data at Naha, and the chemical transport model. In addition to the QBO effect on the lower stratospheric ozone, the middle stratosphere ozone minimum is mainly attributed to the low total ozone, which was also well simulated by the model. In this study, the lower stratospheric ozone was not discussed in de- 


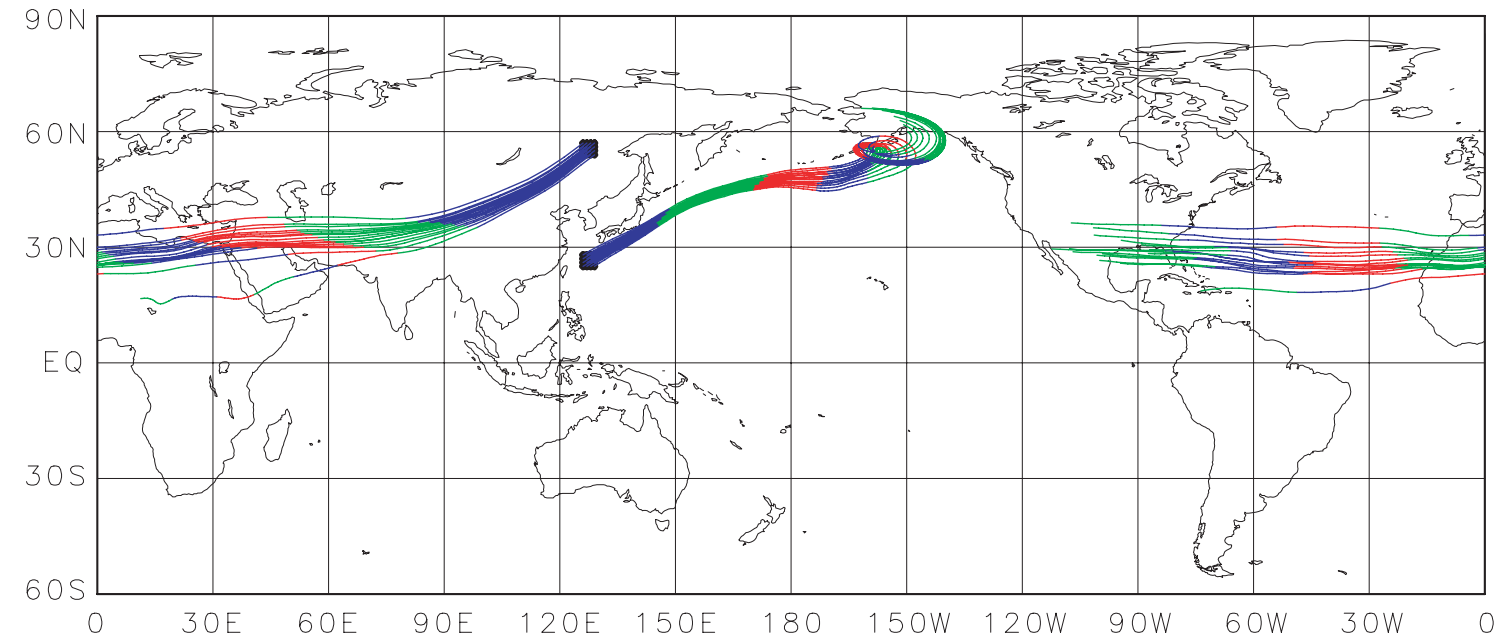

Fig. 13. The 8-day isobaric backward air parcel trajectories at $10 \mathrm{hPa}$ from 12UTC 5 December 2001 at Naha region $\left(25-28^{\circ} \mathrm{N}, 126-129^{\circ} \mathrm{E}\right)$ and Siberia region $\left(55-58^{\circ} \mathrm{N}, 126-129^{\circ} \mathrm{E}\right)$. The initial positions of air parcels are placed in 1 degree intervals both in latitude and longitude and total number of trajectories is $16(=4 \times 4)$. The color of trajectory changes with one day interval.

tails, and the studies are needed in the future. Nevertheless, the present study elucidated that the winter total ozone minimum over the subtropical northwestern Pacific, both in climatological field and in December 2001, is entirely dynamical in origin. Other extreme ozone minima occurring at high winter latitudes in the Atlantic-European sector have also been shown to have a dynamical origin (Hood et al. 2001).

In the northern hemisphere winter, the tropospheric, lower stratospheric and middle stratospheric layers all contribute to the ozone minimum over the subtropical northwestern Pacific. In the southern hemisphere winter, the ozone minimum region is located over Indonesia and the southwestern Pacific region around $10^{\circ} \mathrm{S}$, though the minimum is about $255 \mathrm{DU}$, and it is not so low compared with the northern counterpart. In the southern hemisphere winter, the tropospheric ozone shows the minimum there, but the stratospheric ozone does not show the minimum there (the minimum is found over Africa). Therefore, the winter ozone minimum is a phenomenon quite unique to the northern hemisphere.

\section{Acknowledgments}

This work was supported by a Global Environmental Research Fund (A-1) from the Ministry of the Environment of Japan. We thank H.
Hatsushika and anonymous reviewers for valuable comments on this work. The Grid Analysis and Display System (GrADS) was used for drawing figures.

\section{References}

Dessler, A., 2000: The Chemistry and Physics of Stratospheric Ozone. Academic Press, 214pp.

Dutsch, H.U., 1979: Vertical ozone distribution on a global scale. Pure. Appl. Geophys., 116, 511529.

Fishman, J., C.E. Watson, J.C. Larsen, and J.A. Logan, 1990: Distribution of tropospheric ozone determined from satellite data. J. Geophys. Res., 95, 3599-3617.

Fujii, K., 1994: Numerical Methods for Computational Fluid Dynamics, University of Tokyo Press, 234pp (in Japanese).

Hatsushika, H. and K. Yamazaki, 2003: The stratospheric drain over Indonesia and dehydration within the tropical tropopause layer diagnosed by air parcel trajectories. J. Geophys. Res., 108(D19), 4610, doi:10.1029/2002JD002986.

Hood, L.L., B.E. Soukharev, M. Fromm, and J.P. MaCormack, 2001: Origin of extreme ozone minima at middle to high northern latitudes. J. Geophys. Res., 106, 20925-20940.

Kawahira, K., Y. Iwasaka, and G.-Y. Shi, 2002: The western Pacific ozone low in December 2001. International Symposium on Stratospheric Variations and Climate, 220-221. 
Keating, G.M. and D.F. Young, 1985: Interim reference models for the middle atmosphere. Handbook for MAP, 16, 205-229.

Niwano, M. and M. Shiotani, 2001: Quasibiennial oscillation in vertical velocity inferred from trace gas data in the equatorial lower stratosphere. J. Geophys. Res., 106, 72817290 .

, K. Yamazaki, and M. Shiotani, 2003: Seasonal and $\mathrm{QBO}$ variations of ascent rate in the tropical lower stratosphere as inferred from UARS HALOE trace gas data. J. Geophys. Res., 108(D24), 4794, doi:10.1029/ 2003JD003871.

Plumb, R.A. and R.C. Bell, 1982: A model of the quasi-biennial oscillation on an equatorial beta-plane. Quart. J. Roy. Meteor. Soc., 108, 335-352.

Randel, W.J. and J.B. Cobb, 1994: Coherent variations of monthly mean total ozone and lower startospheric temperature. J. Geophys. Res., 99, 5433-5447.

, A. Gettleman, F. Wu, J.M. Russel III, J. Zawondny, and S. Oltmas, 2001: Seasonal variation of water vapor in the lower stratosphere observed in Halogen Occultation Experiment data. J. Geophys. Res., 106, 14313-14325.

Russell III, J.M., A.F. Tuck, L.L. Gordley, J.H. Park, S.R. Drayson, J.E. Harries, R.J. Cicerone, and P.J. Crutzen, 1993: The Halogen Occultation Experiment. J. Geophys. Res., 98, 1077710797.

Seol, D.I. and K. Yamazaki, 1998: QBO and Pinatubo signals in the mass flux at $100 \mathrm{hPa}$ and stratospheric circulation. Geophys. Res. Lett., 25, 1641-1644.

Shiotani, M., 1992: Annual, quasi-biennial, and El Nino-Southern Oscillation (ENSO) time-scal variations in equatorial total ozone. J. Geophys. Res., 97, 7625-7633.

- and F. Hasebe, 1994: Stratospheric ozone variations in the equatorial region as seen in stratospheric aerosol and gas experiment data. J. Geophys. Res., 99, 14575-14584.

Zhou, L., H. Akiyoshi, and K. Kawahira, 2003: Analysis of year-to-year ozone variation over the subtropical western Pacific region using EP TOMS data and CCSR/NIES nudging CTM. $\bar{J}$. Geophys. Res., 108(D20), 4627, doi:10.1029/ 2003JD003412. 